Mesker WE, Junggeburt JM, Szuhai K, de Heer P, Morreau H, Tanke HJ, Tollenaar RA (2007) The carcinoma-stromal ratio of colon carcinoma is an independent factor for survival compared to lymph node status and tumor stage. Cell Oncol 29(5): 387-398.

Mesker WE, Liefers GJ, Junggeburt JM, van Pelt GW, Alberici P, Kuppen PJ, Miranda NF, van Leeuwen KA, Morreau H, Szuhai K, Tollenaar RA, Tanke H (2009) Presence of a high amount of stroma and downregulation of SMAD4 predict for worse survival for stage I-II colon cancer patients. Cell Oncol 31(3): 169-178.

Moorman AM, Vink R, Heijmans HJ, van der Palen J, Kouwenhoven EA (2012) The prognostic value of tumour-stroma ratio in triple-negative breast cancer. Eur J Surg Oncol 38(4): 307-313.

Park JH, Richards CH, McMillan DC, Horgan PG, Roxburgh CS (2014) The relationship between tumour stroma percentage, the tumour microenvironment and survival in patients with primary operable colorectal cancer. Ann Oncol 25(3): 644-651.
Planche A, Bacac M, Provero P, Fusco C, Delorenzi M, Stehle JC, Stamenkovic I (2011) Identification of prognostic molecular features in the reactive stroma of human breast and prostate cancer. PLoS One 6(5): e18640.

Wang K, Ma W, Wang J, Yu L, Zhang X, Wang Z, Tan B, Wang N, Bai B, Yang S, Liu H, Zhu S, Cheng Y (2012) Tumor-stroma ratio is an independent predictor for survival in esophageal squamous cell carcinoma. J Thorac Oncol 7(9): 1457-1461

Wang Z, Liu H, Zhao R, Zhang H, Liu C, Song Y (2013) [Tumor-stroma ratio is an independent prognostic factor of non-small cell lung cancer]. Zhongguo Fei Ai Za Zhi 16(4): 191-196.

West NP, Dattani M, McShane P, Hutchins G, Grabsch J, Mueller W, Treanor D Quirke P, Grabsch H (2010) The proportion of tumour cells is an independent predictor for survival in colorectal cancer patients. Br J Cancer 102(10): 1519-1523.

Zhang Z, Weaver DL, Munjal K, Evans MF (2014) Intratumoral DNA content heterogeneity in breast carcinomas demonstrated by core punch tissue sampling and flow cytometry. J Clin Pathol 67: 821-824.

*Correspondence: Dr WE Mesker; E-mail: w.e.mesker@lumc.nl

Published online 13 November 2014

(C) 2015 Cancer Research UK. All rights reserved 0007 - 0920/15

\title{
Reponse to: comment on, 'Tumour-stroma ratio (TSR) in oestrogen-positive breast cancer patients'
}

\author{
C L Downey ${ }^{1}$, S A Simpkins ${ }^{1}$, D L Holliday ${ }^{1}$, J L Jones ${ }^{2}$, L B Jordan ${ }^{3}$, J Kulka ${ }^{4}$, A M Hanby ${ }^{1}$ and V Speirs ${ }^{\star}, 1$
}

${ }^{1}$ Leeds Institute of Cancer \& Pathology, University of Leeds, St James's University Hospital, Leeds LS9 7TF, UK; ${ }^{2}$ Centre for Tumour Biology, Barts Cancer Institute, Queen Mary University of London, London, UK; ${ }^{3}$ Department of Pathology, Ninewells Hospital and Medical School, Dundee DD1 9SY, UK and ${ }^{4}$ 2nd Department of Pathology, Semmelweis University Budapest, Üllöi út 93 1091, Hungary

Sir,

We thank Dr Mesker et al for their comments on our study, (Downey et al, 2014) recognising their significant work promoting the concept of using tumour-stroma ratio (TSR) to determine the outcome in cancer (Mesker et al, 2007, 2009; Courrech Stall et al, 2010, 2011; de Kruijf et al, 2011; Dekker et al, 2013; Huijbers et al, 2013).

None of our ER-positive cohort (118 female, 62 males; Downey et al, 2014) received neoadjuvant therapy of any type. Neoadjuvant treatment induces pathological changes in the tumour, hence would render samples unsuitable for TSR analysis. We were limited in the amount of information that could be supplied in a short communication, however univariate and multivariate outcomes were provided.

We found high stromal content was related to better survival across genders in ER-positive disease (Downey et al, 2014), contrasting data in triple-negative breast cancer (de Kruijf et al, 2011) and, as highlighted by Mesker et al, their own work on ER-positive cases (de Kruijf et al, 2011; Dekker et al, 2013). As breast cancer is heterogeneous, subtle differences in stromal biology may exist between breast cancer subtypes, potentially impacting on outcome. Notably, tubular carcinoma, a type of invasive breast ductal carcinoma with an abundant stroma (Figure 1), is almost always ER-positive and has a favourable prognosis (Rakha et al, 2010).

Methodological heterogeneity exists between sampling methods used to assess TSR. Two key issues stand out: (1) lack of standardisation in TSR

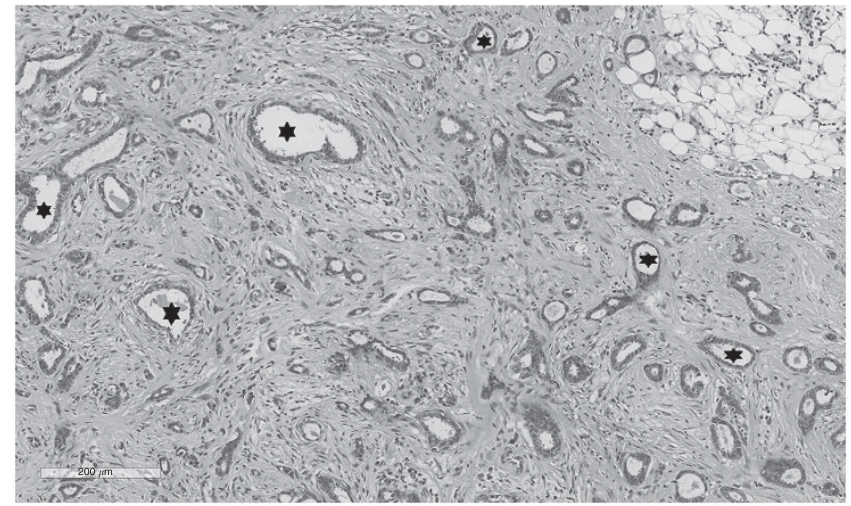

Figure 1. Tubular carcinoma showing arrangement of tumour cells in characteristic tubes (stars) embedded within an abundant multicellular stroma. Scale bar $=200 \mu \mathrm{m}$. measurement, (2) area of tissue selected for analysis. Our in-house computer algorithm method selects a $9 \mathrm{~mm}^{2}$ area of a digitally scanned H\&E image (Downey et al, 2014). Recent related work assessed TSR manually in a single section from the most invasive tumour area (Gujam et al, 2014). Mesker et al favour assessment of the whole slide, even suggesting an evaluation of all available microscope slides. Although rigorous assessment is to be commended, this technique may have practical implications for histopathologists should TSR evaluation ever become routine. Alternative approaches should be considered, compared and validated.

We believe that there is much more to the stroma in dictating outcome, than simply its proportion in relation to tumour. There is a need to examine the cell types that coexist within tumour stroma, for example, fibroblasts and immune cells (Hanahan and Coussens, 2012); a recent issue of this journal showed that patients with a high TSR had significantly reduced inflammatory cell infiltrate within their stroma (Gujam et al, 2014). It remains possible that discrepancies observed between studies of TSR in breast cancer may be due in part to components of the stromal microenvironment.

Consistent with all emerging techniques it takes time for the ideal methodology to become accepted in the field. We respectfully suggest the best way to achieve this for TSR is through collaboration, comparing different techniques, using carefully selected sub groups of breast cancer and working towards reaching a consensus, taking account not only of the stroma but the cells within.

\section{REFERENCES}

Courrech Staal EF, Smit VT, van Velthuysen ML, Spitzer-Naaykens JM, Wouters MW, Mesker WE, Tollenaar RA, van Sandick JW (2011)

Reproducibility and validation of tumour stroma ratio scoring on oesophageal adenocarcinoma biopsies. Eur J Cancer 47: 375-382.

Courrech Staal EF, Wouters MW, van Sandick JW, Takkenberg MM, Smit VT Junggeburt JM, Spitzer-Naaykens JM, Karsten T, Hartgrink HH, Mesker WE, Tollenaar RA (2010) The stromal part of adenocarcinomas of the oesophagus: does it conceal targets for therapy? Eur J Cancer 46: 720-728.

de Kruijf EM, van Nes JG, van de Velde CJ, Putter H, Smit VT, Liefers GJ Kuppen PJ, Tollenaar RA, Mesker WE (2011) Tumor-stroma ratio in the primary tumor is a prognostic factor in early breast cancer patients, especially in triple-negative carcinoma patients. Breast Cancer Res Treat 125 : $687-696$

Dekker TJ, van de Velde CJ, van Pelt GW, Kroep JR, Julien JP, Smit VT, Tollenaar RA, Mesker WE (2013) Prognostic significance of the tumor-stroma ratio: validation study in node-negative premenopausal breast cancer patients from the EORTC perioperative chemotherapy (POP) trial (10854). Breast Cancer Res Treat 139: 371-379.

Downey CL, Simpkins SA, White J, Holliday DL, Jones JL, Jordan LB, Kulka J, Pollock S, Rajan SS, Thygesen HH, Hanby AM, Speirs V (2014) The prognostic significance of tumour-stroma ratio in oestrogen receptor-positive breast cancer. Br J Cancer 110: 1744-1747. 
Gujam FJ, Edwards J, Mohammed ZM, Going JJ, McMillan DC (2014) The relationship between the tumour stroma percentage, clinicopathological characteristics and outcome in patients with operable ductal breast cancer. Br J Cancer 111: 157-165.

Hanahan D, Coussens LM (2012) Accessories to the crime: functions of cells recruited to the tumor microenvironment. Cancer Cell 21: 309-322.

Huijbers A, Tollenaar RA, v Pelt GW, Zeestraten EC, Dutton S, McConkey CC Domingo E, Smit VT, Midgley R, Warren BF, Johnstone EC, Kerr DJ, Mesker WE (2013) The proportion of tumor-stroma as a strong prognosticator for stage II and III colon cancer patients: validation in the VICTOR trial. Ann Oncol 24: 179-185.
Mesker WE, Liefers GJ, Junggeburt JM, van Pelt GW, Alberici P, Kuppen PJ, Miranda NF, van Leeuwen KA, Morreau H, Szuhai K, Tollenaar RA, Tanke H (2009) Presence of a high amount of stroma and downregulation of SMAD4 predict for worse survival for stage I-II colon cancer patients. Cell Oncol 31: 169-178.

Mesker WE, Junggeburt JM, Szuhai K, de Heer P, Morreau H, Tanke HJ, Tollenaar RA (2007) The carcinoma-stromal ratio of colon carcinoma is an independent factor for survival compared to lymph node status and tumor stage. Cell Oncol 29: 387-398.

Rakha EA, Lee AH, Evans AJ, Menon S, Assad NY, Hodi Z, Macmillan D, Blamey RW, Ellis IO (2010) Tubular carcinoma of the breast: further evidence to support its excellent prognosis. J Clin Oncol 28: 99-104.

*Correspondence: Professor V Speirs; E-mail: v.speirs@leeds.ac.uk

Published online 13 November 2014

(c) 2015 Cancer Research UK. All rights reserved 0007-0920/15

http://creativecommons.org/licenses/by-nc-sa/3.0/

$\mathrm{BJC}$

\title{
Comment on 'Reasons for non-uptake and subsequent participation in the NHS bowel cancer screening programme: a qualitative study'
}

\author{
C K Tai ${ }^{*}, 1,4$, P Leung ${ }^{2,4}$, A Poullis ${ }^{1}$ and G Curry ${ }^{3}$
}

${ }^{1}$ Department of Gastroenterology, St George's Hospital, Blackshaw Road, London SW1700T, UK; 'Department of General Surgery, St George's Hospital, Blackshaw Road, London SW170QT, UK and ${ }^{3}$ Bowel Cancer UK, Willcox House, 140-148 Borough High Street, London SE1 1LB, UK

Sir,

We read this paper by Palmer et al (2014) regarding participation in the Bowel Cancer Screening Programme (BCSP) with great interest. At the time of publication we had developed pilot screening education sessions in South London. By running the programme as a group of health care professionals (HCPs) consisting of junior doctors, and in partnership with Bowel Cancer UK, we would assess whether such HCP endorsement improved screening uptake.

South London area has low screening uptake (unpublished data), and consists of many communities of socio-economically deprived and ethnic minority populations. Indeed, previous studies show that such groups correlate with poor screening uptake (Von Wagner et al, 2011; Lo et al, 2014). Bowel Cancer UK has links with these community groups, some of whom invited us to speak, advertising internally to bring our audience. In our pilot phase, sessions have only been one off, but we anticipate returning annually if not more frequently, for new participants as well as to maintain bowel cancer and screening awareness. Education sessions were informal and held at the convenience of participating groups, via a standardised presentation. Participants were given information regarding the epidemiology and risk factors for bowel cancer. In particular, we covered the importance of screening asymptomatic individuals and performed a demonstration and thorough explanation of the faecal occult blood (FOB) test. Participants were encouraged to ask questions before, during and after the presentation, and were sometimes quizzed during the sessions to enable an educational experience that was both informative and enjoyable. Feedback using a Likert scale on how useful the sessions were showed that every participant found the presentation very useful (85.7\%) or quite useful (14.3\%).

In our pilot study, we were invited to deliver talks to 43 participants from three community groups-users of the local library, the local Chinese association and the local Irish pensioners association. Our talks were attended disproportionately by women (male: 13; female: 30 ) due to the variation in participation in these local community groups. For the same reason, our sessions were attended by individuals from a wide range of ages although the majority were aged between 50 and 69 (53.4\%). We did not distinguish between younger (screening naive) and older (screening age) groups in the hope of positively influencing the decision to participate in screening when invited in future in the former group, and consolidating the knowledge and FOB testing know-how in the latter group.

A large proportion of our participants (51\%) were of ethnic minority origin and sometimes interpreters were required for the talks. This is important as screening uptake in ethnic minorities could be poor secondary to the language barrier. This draws attention to the potential influence of discussion to ethnically diverse groups, as Palmer et al held focus groups comprising mostly white Europeans.

Prior to the education sessions, $63.2 \%$ of participants reported awareness of the screening programme with $41.5 \%$ reporting that they would take part. Their willingness to participate in the screening programme improved to $85.7 \%$ after the talk. Before the session, only $27.9 \%$ were aware of the symptoms associated with bowel cancer. This improved to $92.8 \%$ after the talks. Furthermore, $92.8 \%$ reported that they would see their GP if they were to experience any symptoms associated with bowel cancer. Moreover, $82.1 \%$ felt more comfortable talking about bowel cancer and the screening programme with friends and family. This increased willingness to participate in the screening programme after the educational programme draws parallels to the findings by Palmer et al, after their participants had the opportunity to discuss screening with others. However, despite the improvement in the understanding of bowel cancer and risk factors, only $23-50 \%$ expressed willingness to make lifestyle changes such as smoking cessation. Annual sessions would serve as follow-up to assess whether participants actually took part in screening after an educational session.

Although our pilot study looked at a very small number of participants, our results have been consistent with the qualitative data collected by Palmer et al in showing the benefits of discussion to dispel misconceptions and also to encourage and support participation in the screening programme. Palmer et al reported that many participants claimed they were more likely to participate in FOB testing if it were endorsed by HCPs. Further research with larger groups of people may prove to be beneficial in assessing whether running wide-scale HCPendorsed bowel cancer screening is cost-effective to bring long-term improvement to the uptake of bowel cancer screening.

\section{REFERENCES}

Lo SH, Halloran S, Snowball J, Seaman H, Wardle J, von Wagner C (2014)

Colorectal cancer screening uptake over three biennial invitation rounds in the English bowel cancer screening programme. Gut; e-pub ahead of print 7 May 2014; doi:10.1136/gutjnl-2013-306144.

Palmer CK, Thomas MC, von Wagner C, Raine R (2014) Reasons for non-uptake and subsequent participation in the NHS bowel cancer screening programme: a qualitative study. Br J Cancer 110(7): 1705-1711.

Von Wagner C, Baio G, Raine R, Snowball J, Morris S, Atkins W, Obichere A, Handley G, Logan RF, Rainbow S, Smith S, Halloran S, Wardle J (2011) Inequalities in participation in an organized national colorectal cancer screening programme: results from the first 2.6 million invitations in England. Int J Epidemiol 40(3): 712-718.

\footnotetext{
*Correspondence: Dr CK Tai; E-mail: Chehkuan.tai@gmail.com

${ }^{4}$ These authors contributed equally to this work.

Published online 4 November 2014

(c) 2015 Cancer Research UK. All rights reserved 0007-0920/15
}

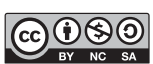

http://creativecommons.org/licenses/by-nc-sa/3.0/ ${ }_{\text {OPEN }}^{B J C}$ 